\title{
13 Hobbes and the Cause of Religious Toleration
}

Many readers of Leviathan will be surprised by the suggestion that in that work Hobbes might have been - in intention and in act - a friend of religious toleration. Who could be further removed, on this issue, from that 'saint of liberalism', I John Locke? Locke's Letter on Toleration sought a kind of separation of church and state, ${ }^{2}$ arguing that each of these institutions has its own areas of legitimate concern, that the state exists to protect our temporal interests, and is entitled to use force to do so, but that it cannot use coercion to advance our spiritual interests. These are the province of the churches, which also cannot use force to achieve their ends. Since a saving faith must be uncoerced, they must rely on persuasion. Hobbes is certainly not a saint of liberalism in that sense. He advocates, not a separation of church and state, but a subordination of the church to the state.

On Hobbes's view it is an essential prerogative of the sovereign to determine what books may be published and what doctrines may be taught, in public gatherings generally, but especially in the universities and the churches. ${ }^{3}$ He thinks the sovereign must not only see that doctrines harmful to peace are not taught but also ensure that doctrines promoting his absolute authority are taught. The Hobbesian sovereign is meant to exercise a very broad control of public discourse, in philosophy, in science, in politics and morals,

This is a revised version of a paper presented to the Eric Vögelin Society, at the meeting of the American Political Science Association in Washington, September 2005. I'm indebted to the participants in that session for their comments on the earlier version, and to Patricia Springborg and Liz Anderson for their comments on subsequent versions. 
and especially in religion. The fundamental purpose of his control is to prevent sedition.

Among the doctrines Hobbes regards as particularly seditious are two that many Christians in his day would have thought firmly based in Scripture: that 'faith and sanctity are not to be attained by study and reason, but by supernatural inspiration or infusion' (Lev., xxix, 8, I69/2 I 2-I3) and that 'whatsoever a man does against his conscience is $\sin ^{\prime}\left(\right.$ LeV., $x x i x, 7$, I68-9/2 I 2). ${ }^{4}$ Since the rights of conscience were in Hobbes's day often invoked in favor of toleration, his rejection of the latter doctrine would be particularly troubling to its contemporary advocates. The sovereign's many rights include the right to determine which books of Scripture are canonical (LeV., xxxiii, I, I99-200/250-I), the right to decide how we should interpret passages in those books (Lev., xxxiii, 25, 206/26I), and the right to give legal force to the teachings of Scripture (LeV., xxvi, 4I, I49-50/I8789; Lev., xxxiii, 24, 205-6/259-6I).

So it was a pleasant paradox, about twenty years ago, when Alan Ryan published two papers suggesting that Hobbes might be more friendly to toleration than we generally give him credit for being. ${ }^{5}$ Among other things, Ryan noted that Hobbes's position leaves room for a large measure of toleration because his argument for imposing uniformity is essentially a pragmatic, political one. There are some opinions in religion that are dangerous to the peace and order of society, either because they may encourage subjects to rebel against their sovereign - notably the doctrine that we must obey God rather than man (Acts 5:29) - or because they may cause subjects to divide into factions and kill one another, as had frequently happened in the wars of religion of the sixteenth and seventeenth centuries. ${ }^{6}$ The sovereign may, and should, vigorously repress the expression of those opinions. But he should not care what people think privately, so long as they keep it to themselves and do not act antisocially. ${ }^{7}$ Unlike the true believer, whose goal is to save souls, the Hobbesian sovereign looks only to temporal ends and can justify imposing uniformity just to the extent that doing so helps him to achieve those temporal ends.

Not only does the pragmatic nature of Hobbes's argument leave room for a large measure of toleration, it also leads Hobbes to endorse leaving people alone when it is not necessary, for the good of the commonwealth, to interfere with them. The duty of the sovereign is to seek the well-being of his people (Lev., xxx, I, I75/2I9). One 
aspect of that well-being is what Hobbes calls, in The Elements of Law, 'commodity of living'. Part of commodity of living is liberty, by which Hobbes there means 'That there be no prohibition without necessity of any thing to any man which was lawful to him in the law of nature, that is ..., that there be no restraint of natural liberty, but what is necessary for the good of the commonwealth' ${ }^{8}$ He reaffirms this view in Leviathan, when he argues that the sovereign has a duty to make only good laws, where the goodness of a law is measured by its necessity for the good of the people. (LeV., xxx, 2I, I82/229)

Hobbes claims in the Dedicatory Letter to Leviathan that he has tried to find a middle course between those who seek too much liberty and those who seek too much authority. Most readers of Leviathan have felt that he tilted too far in the direction of authority, and that is an understandable reaction to the positions described at the beginning of this paper. But to do Hobbes justice we must acknowledge those aspects of his thought that bring him closer to the center. One reason why Hobbes rejects repression of thought and expression beyond what is necessary for the good of the commonwealth is that he thinks it is counterproductive, provoking bitterness and resentment, and undermining the loyalty of the sovereign's subjects. In Behemoth he writes: 'A state can constrain obedience, but convince no error, nor alter the minds of them that believe they have the better reason. Suppression of doctrine does but unite and exasperate, that is, increase both the malice and power of them that have already believed them' ${ }^{\prime}{ }^{9}$ This may exaggerate the limits on the state's ability to produce uniformity in the area of religion. The Spanish and Portuguese Inquisitions, with the help of 'the secular arm', seem to have been pretty effective in preventing the Reformation from spreading to those countries. But in the passage quoted Hobbes is clearly thinking of the results of Archbishop Laud's attempts to suppress the teaching of predestination and to impose the Book of Common Prayer on the Scots. ${ }^{\text {IO }}$

Where Ryan argued merely that Hobbes was more favorable to toleration than we might have thought, Richard Tuck subsequently claimed that Leviathan is actually 'a defense of toleration'. ${ }^{\text {II }}$ This probably goes too far, at least if we restrict ourselves to the first published version of Leviathan, the English edition of I65 I. Later we will look at the passage in that work that constitutes Tuck's best evidence for this proposition. But Tuck reminds us, usefully, that 
between I666 and I670 Hobbes wrote a number of works - the Dialogue between a Philosopher and a Student of the Common Laws of England, the Appendix to the Latin Leviathan, the Historical Narration Concerning Heresy, Behemoth, and the Historia Ecclesiasticain which he argued that since the Long Parliament abolished the High Commission, there was no basis in English law for the prosecution of heresy. ${ }^{\mathrm{I} 2} \mathrm{He}$ also implied rather strongly that there should not be. This implication surfaces, for example, in the conclusion of Hobbes's discussion of the Nicene Creed: 'The things the Fathers say outside Sacred Scripture in their individual explanations of the faith [e.g., in the decisions of church councils, like that held at Nicaea] do not oblige Christians, each of whom ought to search out his own salvation in Sacred Scriptures, not at another's risk, but at his own, very great risk' ${ }^{13}$ Similarly in the second chapter of the Appendix Hobbes invokes the parable of the weeds in the wheat of Matthew I 3:27-30 to show that the punishment of heresy should be left to God at the last judgement. ${ }^{14}$

These positions would surely exclude the imposition on the whole population of the Nicene Creed, a move contemplated in the Act of Uniformity considered by Parliament in I667. Tuck argues that in opposing the intolerant policies advocated by the Anglicans and Presbyterians in the late I66os, Hobbes was siding with 'the former Independents and other theological radicals from the Civil War years' and that this aligned him politically with 'the Cabal', the group of five government ministers, led by Shaftesbury, who replaced Clarendon as Lord Chancellor in I667. Since Locke was then working as an aide to Shaftesbury, and beginning to develop his own defence of toleration, ${ }^{\mathrm{I}}{ }^{5}$ this made Hobbes and Locke political allies, at least with respect to the issue of religious toleration!

Tuck also reminds us that during this period from I666-I670 Hobbes had his own personal reasons to fear religious intolerance. Beginning in the fall of I666, and as late as the summer of I668, Parliament was discussing, off and on, two forms of a bill 'against atheism and profanity'. The stronger of the two versions explicitly made it an offence, punishable by imprisonment or banishment, to deny such doctrines as the Trinity, or God's providence, or the divine authority of the books accepted as canonical in the Church of England, or the immortality of the soul, or the eternal torment of the wicked in hell. Each of these doctrines was one Hobbes might 
plausibly be thought to have denied in Leviathan. Indeed, the committee in the House of Commons considering the earlier (and weaker) of the two bills was empowered to collect information specifically about Leviathan, and there was a motion in the House that Leviathan be burned. Aubrey says Hobbes heard a report that 'some of the bishops made a motion to have the good old gentleman burned for a heretic. Which he hearing, feared that his papers might be searched by their order, and he told me that he had burned part of them' ${ }^{16}$ Hobbes himself was summoned to appear before a committee of the House of Lords in I667. In the end these bills did not pass, and Hobbes was not burned. ${ }^{17}$ But these events must have given him a good scare, and a strong motive to support the toleration of religious difference.

Hobbes's support for toleration is not, however, entirely a response to the events of the late I66os. Even in the English Leviathan of I65 I Hobbes had criticized the Roman Church's condemnation of Galileo as presupposing a misunderstanding of the purpose of Scripture, which in his view was to teach us how to achieve the Kingdom of God, not what the nature of the universe is (viii, 26, 38-9/45-6). Moreover, in chapter xliii of Leviathan he had argued that the path to the Kingdom is easy:

All that is necessary to salvation is contained in two virtues: faith in Christ and obedience to laws. The latter of these, if it were perfect, were enough to us. But because we are all guilty of disobedience to God's law, not only originally in Adam, but also actually by our own transgressions, there is required at our hands now, not only obedience for the rest of our time, but also remission of sins for the time past, which remission is the reward of our faith in Christ. (LeV., xliii, 3, 322/398-9)

There are two things to notice about these requirements. First, you might think the reference here to obeying God's law implies that salvation requires adherence to the commandments of Scripture. But it does not. The law of Moses is not binding on Christians, and Jesus, according to Hobbes, issued no new commandments. He only counseled us to obey the laws we are already subject to [i.e., 'the laws of nature and the laws of our several sovereigns' (Lev., xliii, 5, 322/399-400)]. Counsel is not command, and so lacks an essential feature of laws. ${ }^{18}$ If we obey the laws of the state and the laws of nature - where the latter require action only if there is reasonable 
assurance of reciprocity (Lev., xv, 36, 79/99) - we will have satisfied the requirement of obedience to laws.

Second, the faith in Christ Hobbes thinks required is not a belief that Jesus was divine. It is a belief that Jesus is the Christ, which Hobbes interprets to mean that Jesus was the Messiah, 'the king God had before promised, by the prophets of the Old Testament, to send into the world to reign (over the Jews and over such of other nations as should believe in him) under himself eternally, and to give them that eternal life which was lost by the sin of Adam' (Lev., xliii, I I, 324/402). If, to be saved, we had to assent to 'all the doctrines concerning Christian faith now taught (whereof the greatest part are disputed)... there would be nothing in the world so hard as to be a Christian' (Lev., xliii, I4, 325/403). But the faith necessary for salvation is easy: the thief who died with Jesus on the cross showed that he had it when he testified to his belief that Jesus was the king; and the Jews of Jesus' time could have had it, simply by accepting that Jesus was the Messiah foretold in the Old Testament (Lev., xliii, I $5,326 / 403-4)$.

This kind of minimalism about the requirements for salvation had been a popular argument for toleration ever since the mid-sixteenth century, when Castellio protested against the burning of Servetus in Geneva for having propagated his heretical interpretation of the doctrine of the Trinity. Though Hobbes probably carries doctrinal minimalism further than Castellio would have, he does have some claim to being an advocate of 'Erasmian liberalism', 19 which emphasizes conduct at the expense of doctrine, suspends judgement on many theological issues, and insists that the faith required for salvation is simple and uncontroversial, at least among Christians. This move tends to undermine the claim that the suppression of heresy is necessary, not to save the heretics, but to save those so-far-faithful Christians whom the heretics might lead astray if they were permitted to defend their heresies, a goal that both Aquinas and Calvin had invoked to justify the suppression of heresy. ${ }^{20}$

But there is another side of Leviathan, which we have not yet considered. Insofar as Hobbes is an Erasmian liberal, he stands with Castellio, Locke and those moderate Enlightenment figures who attempted to make a case for religious toleration within the framework of Christianity, broadly construed. But though Hobbes has one foot in the moderate mainstream of the Enlightenment, he has the 
other in the radical Enlightenment Jonathan Israel describes in his book of that title. ${ }^{2 \mathrm{I}}$ By the 'radical Enlightenment' Israel understands an intellectual movement that,

whether on an atheistic or deistic basis, rejected all compromise with the past and sought to sweep away existing structures entirely, rejecting the Creation as traditionally understood in Judeo-Christian civilization, and the intervention of a providential God in human affairs, denying the possibility of miracles, and reward and punishment in an afterlife, scorning all forms of ecclesiastical authority, and refusing to accept that there is any God-ordained social hierarchy, concentration of privilege or land-ownership in noble hands, or religious sanction for monarchy. (pp. I I-I 2)

Israel thinks that Spinoza played a central role in this movement, but denies that Hobbes was comparably important (p. I 59). I think he is right about Spinoza, but wrong about Hobbes. ${ }^{22}$

It is true, of course, that Hobbes is not openly atheistic or deistic, ${ }^{23}$ and he certainly does not want to sweep away existing structures entirely. But then Spinoza's own religious position is ambiguous enough that some readers have thought he was a Christian. ${ }^{24}$ And like Hobbes, Spinoza used secular arguments to defend the political structures that existed prior to the crises of his day. (The difference is that in the Netherlands of I670 the status quo Spinoza defended was republican, not monarchical.) The affinities between Hobbes and Spinoza are really quite deep. It is true that Hobbes is not as bold as Spinoza in what he says about the creation. Spinoza clearly commits himself to the eternity of the world (Ethics I, Prop. 28). Hobbes's official teaching rejects the eternity of the world, but in his 'rejection' Hobbes mocks the arguments of those who use the paradoxes of infinity to show that the world must have had a beginning: 'Do not those who in this way take away the eternity of the world also, by the same act, take away the eternity of the world's maker?'25 Because the arguments of the creationists involve the concept of infinity, which Hobbes says is beyond our comprehension, philosophers cannot settle this question by using natural reason. So he contents himself with affirming creation out of respect for Scripture and the customs and laws of his country. But since he holds that Scripture's aim is not to inform us about the nature of the world, only to show us how to achieve salvation (Lev., viii, 26, 38-9/45), what this amounts to is that he accepts creation because the customs and laws 
of his country do so. If the customs and laws of his country required acceptance of the eternity of the world, presumably that is what he would accept. ${ }^{26}$

Again, whereas Spinoza clearly denies that God is providential, when he denies his God intellect, will, and ends (Ethics I, Prop. 3 I and App.), Hobbes does not clearly deny divine providence. But he does interpret that doctrine in a way that would offer no comfort to the afflicted. As Hobbes reads the Book of Job (LeV., xxxi, 6, I 88/236-7), God's existence gives us no reason to think that what happens in the world is part of the plan of an omnipotent, omniscient and loving God, and that therefore there must be a good reason for whatever suffering occurs. God's absolute power makes whatever he chooses to do right, even if it involves inflicting horrendous suffering on an innocent man. There is a tension between this theology and the covenant theology of the Pentateuch, a tension that emerges clearly in Leviathan. Covenant theology commits God to rewarding obedience and punishing disobedience; Hobbes's God cannot be bound by any promises. ${ }^{27}$ Moreover, not only would Hobbes's doctrine that God has no ends ${ }^{28}$ make it difficult to defend a traditional conception of divine providence, it also, given Hobbes's definitions of law and command, entails the spinozistic heresy that God cannot be a lawgiver. ${ }^{29}$

Again, whereas Spinoza denies that miracles are even metaphysically possible, ${ }^{30}$ Hobbes does not deny that they occur. He just cautions us to be wary of believing in any particular miracle:

Such is the ignorance and aptitude to error generally of all men (but especially of them that have not much knowledge of natural causes and of the nature and interests of men) as by innumerable and easy tricks to be abused.... If we look upon the impostures wrought by confederacy, there is nothing how impossible soever to be done, that is impossible to be believed. For two men conspiring, one to seem lame, the other to cure him with a charm, will deceive many; but many conspiring, one to seem lame, another so to cure him, and all the rest to bear witness, will deceive many more. ${ }^{3 \mathrm{I}}$

Though Hobbes's argument here - like Hume's and unlike Spinoza's is epistemological rather than metaphysical, he does anticipate Spinoza insofar as he suggests that someone who understood natural causes would be much less easily taken in by false tales of miracles.

Spinoza's views on immortality are more difficult to work out. Early in the Ethics he says that mind and body are one and the 
same thing, conceived under different attributes (II, Prop. 2 I, Schol.), which would seem to entail that the mind must die with the body. Later he says that there is something of the mind that is not destroyed with the body, but is eternal (V, Prop. 23). But whatever part of the mind is eternal - apparently it is the part that has intellectual knowledge of God or Nature - lacks any memory of a life in the body. Since Spinoza makes memory essential to personal identity (IV, Prop. 39, Schol.), this entails a denial of personal immortality. Spinoza construes hell as something lived here on earth, when we are subject to such passions as sadness, despair, envy, terror, and the like. ${ }^{32}$ Hobbes does not deny immortality. But consistently with his materialism, he conceives of the life eternal as enjoyed, not by an immaterial soul, but by a resurrected body, which will live in a terrestrial paradise (Lev., xxxviii, I-5, 238-42/30I-5). The wicked do not have eternal life and are not punished for eternity. After their 'first death', they are punished, but not forever. When they have suffered enough, they die a 'second death' (i.e., are annihilated). ${ }^{33}$

Among Hobbes's many affinities with Spinoza, one of the most important is his role in the emerging science of biblical criticism. ${ }^{34}$ Not only does Hobbes anticipate Spinoza in denying the Mosaic authorship of the Pentateuch, he also anticipates his view that all the books of the Old Testament were compiled many centuries after the events they describe. He even anticipates Spinoza in identifying the post-exilic priest, Ezra, as the person who probably put the central historical books of the Bible into the form in which we have received them (Lev., xxxiii, I9, 203/255-6). But Hobbes is not as bold as Spinoza in the conclusions he explicitly draws from his biblical criticism. Nowhere does he write anything as blunt as Spinoza's claim that 'the word of God is faulty, mutilated, corrupted and inconsistent, that we have only fragments of it, and that the original text of the covenant God made with the Jews has been lost'. ${ }^{35}$ Indeed, Hobbes makes a point of denying that the temporal gap between the events recorded and the earliest surviving records of those events casts doubt on the records' accuracy: 'I see not therefore any reason to doubt but that the Old and the New Testaments, as we have them now, are the true registers of those things which were said and done by the prophets and apostles' (Lev., xxxiii, 20, 204/257). But his grounds for this conclusion are odd.

Hobbes acknowledges that the interval between the events recorded and the texts describing those events is not as great in the 
case of the New Testament books as it is in the case of the Old. The authors of the New Testament books all lived in the age of the apostles (i.e., in the mid-first century). But then he observes that there was a significant temporal gap between the writing of the New Testament books and their inclusion in the canon, that is, the authoritative determination of their sacred status and their official recommendation to Christian congregations. He dates their acceptance as canonical as having occurred near the end of the fourth century. During that gap there were only a few copies of the works available, and they were in the hands of ambitious priests, who wished to exercise control over the emperors and were willing to use pious fraud to gain that control. But although these priests had both the motive and the opportunity to alter the texts to their liking, Hobbes writes,

I am persuaded they did not therefore falsify the Scriptures (though the copies of the books of the New Testament were in the hands only of the ecclesiastics), because if they had had an intention to do so, they would surely have made them more favourable to their power over Christian princes and civil sovereignty than they are. (xxxiii, 20, 204/257)

In "'I Durst Not Write So Boldly"' (p. 569) I argued that Hobbes was being ironic here. He put together an argument that we might naturally think led to one conclusion - that our present texts of the Old and New Testaments do not provide a reliable record of the things said and done by the prophets and apostles - but then denied that conclusion, for reasons we should not find, and are not expected to find, convincing. I called this 'suggestion by disavowal'. The author suggests a heretical conclusion but avoids having to take responsibility for it by giving us bad reasons for denying that it follows from his premises. A general skepticism about the accuracy of Scripture as a record of what the prophets and apostles said and did would serve Hobbes's purposes by diminishing the authority of Scripture as a basis for belief, thereby weakening a principal ground alleged for disobedience to the sovereign. Moreover, since scriptural texts affirming the necessity of correct belief for salvation - like John 3: I 6I 8 - are also a crucial part of the case for punishing heresy, diminishing the authority of Scripture also serves the cause of religious toleration.

One reason I thought Hobbes was being ironic was that his professed reason for accepting the counterconclusion (i.e., for thinking 
that the present texts of the Old and New Testaments do provide a reliable record of the events they describe) was patently insufficient to support that conclusion. Is deliberate alteration of the text the only way error could have crept in? Might not the scientific ignorance or credulity of the authors have led them to treat as miraculous events that had a natural explanation? And even if the priests who preserved the texts of the New Testament did not deliberately alter them to make them more favorable to their temporal power, what assurance does that give us that those who were responsible for writing and transmitting the texts of the Old Testament gave us a true register of what happened many centuries before they wrote? The fact that one group of priests did not alter the texts in their care does nothing to show that another group of priests, who had the disadvantage of living long after the events their texts described, were both able and willing to transmit an accurate account of those events.

Recently Noel Malcolm has considered the possibility of interpreting this passage ironically, and cautioned that we cannot decide, on the basis of this passage alone, what Hobbes's intentions are. He notes that Bellarmine had used a similar argument against the possibility that the rabbis had corrupted the text of the Old Testament. 'If they had wished to falsify the holy Scriptures out of hostility to the Christians', Bellarmine wrote, 'they would doubtless have removed the main prophecies [of the Messiah]'. ${ }^{36}$ No one would accuse Bellarmine here of suggestion by disavowal. Malcolm does not flatly reject the ironic interpretation, but suggests that if we accept it, we must do so on the basis of larger contextual considerations, such as Hobbes's 'naturalistic treatment of miracles and prophecy, and his epistemological blocking of any transmission of divine revelation from one human being to another'. Malcolm's caution is judicious. I would agree that these contextual considerations are very helpful in, and perhaps necessary for, determining the meaning of this passage. But a dogged defender of a nonironic interpretation of the text is apt to question our interpretation of the passages about miracles, prophecy and revelation too. So it may be useful to see what more can be mined from this passage.

We might begin by noting one disanalogy between Bellarmine's argument and Hobbes's. Many copies of the Hebrew Bible, not only in the original language, but also in Greek translation, were circulating 
by the time the Christians became a force the rabbis had to contend with. So it would not have been as easy for the rabbis to falsify their Scriptures as Hobbes insists it was for the Christian clerics. (This weakens Bellarmine's argument. Does it strengthen Hobbes's?) Moreover, Hobbes's argument should raise the following question in the minds of critical readers: if the priests had the motive and the opportunity to falsify the texts, what stopped them from doing so? We might have hoped that they would have been inhibited by moral scruples about tampering with the word of God. But Hobbes has blocked that response in advance by telling us that these priests 'thought such frauds as tended to make the people more obedient to Christian doctrine to be pious'.

Hobbes cites no evidence for this claim, but if challenged to do so, he might have offered the example of the 'Johannine comma', that variation of I John 5:7-8, which imports a clear statement of the doctrine of the Trinity - the only clear statement of that doctrine in the New Testament - into a passage that evidently did not originally contain it. In the sixteenth century Erasmus had created an uproar when he omitted the Johannine comma from the first printed edition of the Greek New Testament, on the ground that he did not find it in the Greek manuscripts available to him. When critics protested the omission, Erasmus offered to restore the passage if someone could show him a Greek manuscript that contained it. A manuscript containing it was accordingly produced, and in subsequent editions of the New Testament Erasmus restored the passage, though his annotation expressed doubts about the authenticity of the new manuscript. And indeed, it is now generally regarded as a forgery, produced for the occasion. ${ }^{37}$ Given Hobbes's intense interest in the doctrine of the Trinity, it seems likely that he would have known about this case, though he does not challenge the authenticity of the Johannine comma when he discusses it in chapter xlii of Leviathan, preferring instead to interpret it in a way consistent with his position on the Trinity. ${ }^{38}$

Reflection on this case also points up another weakness in Hobbes's argument for his counterconclusion: when the priests transmitted the text, they might have been more concerned with theological issues than with claiming authority over rulers. As we have learned since Hobbes's day, there are numerous examples where 
the texts of our earliest manuscripts of the New Testament seem to have been deliberately altered to make them favor one side over another in the disputes about Jesus' nature which bitterly divided his followers in the first centuries after his death. ${ }^{39}$ At least by the time he wrote the Latin Leviathan Hobbes was well informed about the many 'heresies' in the early church, and knew that the term heresy (hairesis) did not acquire its pejorative meaning until after the early church councils defined what orthodoxy comprised. $4^{\circ}$

An ironic reading of Hobbes's conclusion thus seems to me perfectly in order, although I would not dream of imputing irony to the similar argument in Bellarmine. What makes the difference? Certainly context is important. Hobbes is an author in whom we frequently find passages that seem to flirt with heresy, if they do not embrace it outright. ${ }^{4 \mathrm{I}}$ Bellarmine is not. But the contemporary reception of Hobbes is also important. Most of his contemporaries thought Hobbes was highly unorthodox. We need to be able to account for that reaction. A reading of Hobbes that acknowledges his frequent use of irony helps us to do so.

One important affinity Hobbes had with Spinoza and other authors of the radical Enlightenment is that he did 'scorn all forms of ecclesiastical authority'. Aubrey quotes a suggestive remark made to him by Edmund Waller: 'that what was chiefly to be taken notice of in [Hobbes's] elegy was that he, being but one, and a private person, pulled down all the churches, dispelled the mists of ignorance, and laid open their priestcraft'. ${ }^{42}$ No doubt Waller exaggerated Hobbes's actual accomplishments when he said that. Hobbes did not in his own time succeed in dramatically weakening the political power of authoritarian religion, though he may in the long run have contributed significantly to weakening it. But I do not think he much exaggerated Hobbes's goals. As we shall see, Hobbes is not opposed to all churches, in the most general sense of the term 'church'. But he is opposed to churches that claim to exercise authority over us, churches that make a sharp distinction between the laity and the clergy, and whose clergy, in virtue of their presumed superior knowledge of spiritual matters, claim the right to issue decrees it is unjust to disobey, independently of the decrees of the sovereign. ${ }^{43}$ It is these churches that pose a threat to the authority of the sovereign, and it is these churches that must be 'pulled down'. 
This agenda is most evident in Part IV of Leviathan, titled 'The Kingdom of Darkness'. Hobbes defines the kingdom of darkness as 'a confederacy of deceivers that, to obtain dominion over men in this present world, endeavor by dark and erroneous doctrines to extinguish in them the light, both of nature and of the gospel, and so to disprepare them for the kingdom of God to come' (Lev., xliv, I, 333/4I I). Hobbes also refers to the kingdom of darkness as the kingdom of Satan and says that the darkest part of it consists of those who reject Christ. He offers no evidence to suggest that non-Christians are conspiring among themselves to obtain dominion over Christians. The members of this confederacy of deceivers whom he thinks most dangerous - if we may judge by the attention he gives them are the leaders of the Roman Catholic Church, whose Pope claims, as Christ's vicar on earth, a right to the obedience of all Christians (whether Catholic or not), a right, through his bishops, to crown kings (Lev., xliv, 6-9, 335-7/4I3-I5), and a right to release subjects from their obligation to obey their king, if he is not diligent in purging his country of heretics (Lev., xliv, 6-9, 335-7/4I3-I5).

Still, it would be a mistake to think that Hobbes's polemic against the kingdom of darkness has only the Catholic Church as its target. Though he devotes what some readers may feel is an inordinate amount of space in books III and IV of Leviathan to his campaign against that church, he also makes it clear that he finds the Presbyterian clergy equally obnoxious: 'The Presbytery hath challenged [i.e., claimed] the power to excommunicate their own kings, and to be the supreme moderators in religion, in the places where they have that form of Church government, no less than the Pope challengeth it universally' (LeV., xliv, I7, 340-I/420-I). An attack on Presbyterianism was not only an attack on the Church of Scotland. In I647 the Westminster Assembly had approved and in I648 Parliament had ratified a common confession, intended to unite the Christian churches of England, Scotland and Ireland. ${ }^{44}$ Although the political power of the Presbyterians declined sharply after Pride's Purge in December I648, the Church of England itself still contained many Presbyterians. ${ }^{45}$

Hobbes's fierce anticlericalism is not news, of course. But we may not appreciate its relevance to the problem of religious toleration. Hobbes views the clergy as an inherent threat, not only to the authority of the king, but also to religious liberty. Clerics may be 
men of God, but they are still men, and one thing Hobbes thinks is common to all men is 'a perpetual and restless desire of power after power, which ceaseth only in death' (Lev., xi, 2, 47/58). If we consider power in its broadest sense, as the present means to obtain some future apparent good (Lev., x, I, 4I/5o), there is nothing inherently wrong with the desire for power. It is only rational to desire the means to whatever else you may desire. But people do not differ greatly in their natural ability to get what they want (Lev., xiii, I, $60 / 74)$. Significant differences of power arise only when some men are able to use their natural power to get others to do their bidding, acquiring thereby a kind of power Hobbes calls 'instrumental' (Lev., $\mathrm{x}, 2-3,4 \mathrm{I} / 5 \mathrm{O})$. Because people may differ greatly in their degree of instrumental power, it can be much more dangerous than natural power.

The clergy are particularly well placed to acquire instrumental power. For another common feature of human nature is our ignorance of natural causes and, in particular, of the causes of our good or ill fortune (LeV., xii, I-6, 52/63-4). This ignorance makes us anxious about the future (Lev., xii, 5, 52/63-4), credulous (LeV., xi, 23, 5I/62) and thus prone to take things that happen accidentally as good or evil omens. It disposes us to trust those who can plausibly claim the power to foresee the future and to assist us in realizing our goals (Lev., xii, IO, 54/66). These human weaknesses are among the 'natural seeds' of religion, which Hobbes defines as a 'fear of invisible powers, feigned by the mind, or imagined from tales publicly allowed' (Lev., vi, 36, 26/3 I). These natural seeds of religion would not have blossomed into the organized religions we find around us if there had not been men who cultivated them (Lev., xii, I2, 54/67). Hobbes allows that some of these men - the founders of the true religion - cultivated the seeds of religion at God's direction. Others - the founders of the pagan religions - were acting on their own. But both sorts of men, he contends, were motivated by a desire to make their fellow men more obedient. More obedient to whom or what? The English version of Leviathan attributes an apparently benign motive to the founders of religions: 'Both sorts have done it with a purpose to make those men that relied on them the more apt to obedience, laws, peace, charity, and civil society'. The Latin version says, less amiably, that they have done it to make 'their initiates more obedient to themselves'. 
It is not surprising, then, that when Hobbes comes to analyze the motivations that underlie the kingdom of darkness, he fixes on the desire for power:

In those places where the Presbytery took that office [of administering the government of religion], though many other doctrines of the Church of Rome were forbidden to be taught, yet this doctrine (that the kingdom of Christ is already come, and that it began at the resurrection of our Saviour) was still retained. But cui bono? What profit did they expect from it? The same which the Popes expected: to have a sovereign power over the people. (Lev., xlvii, 4, 382/478)

There is a similar warning in Hobbes's discussion of prophecy:

Men had need to be very circumspect and wary in obeying the voice of man that, pretending himself to be a prophet, requires us to obey God in that way which he in God's name telleth us to be the way to happiness. ${ }^{46}$ For he that pretends [i.e., claims] to teach men the way of so great felicity pretends to govern them (that is to say, to rule and reign over them), which is a thing that all men naturally desire, and is therefore worthy to be suspected of ambition and imposture, and consequently ought to be examined and tried by every man before he yield them obedience. (LeV., xxxvi, I9, 230/290)

Hobbes does not, of course, deny that prophecy has occurred. He just warns us to be suspicious of anyone who claims to be a prophet. And his reasoning would apply equally to any minister who claimed to be able to tell us the way to salvation.

Hobbes's suspicion of the clergy has clear implications for the Scriptures on which they base their authority. In his discussion of faith earlier in Leviathan Hobbes had written: 'When we believe that the Scriptures are the word of God, having no immediate revelation from God himself, our belief, faith and trust is in the church, whose word we take, and acquiesce therein' (Lev., vii, 7, 32/37). It seems reasonable to infer from this that if we cannot trust the clergy, we cannot trust that Scriptures are the word of God. That Hobbes affirmed the antecedent of this conditional can hardly be doubted.

Earlier I said I did not think Hobbes wanted to 'pull down' all the churches. My evidence for this is a remarkable passage toward the end of the last chapter of Leviathan, where Hobbes gives an abridged history of the Christian religion, with an emphasis on the problem of religious liberty. In the beginning, he says, the people obeyed the apostles out of reverence for their wisdom, humility, sincerity and other virtues, not out of obligation. 'Their consciences were free, and 
their words and actions were subject to none but the civil power' (Lev., xvlii, I9, 384/48I). But as the religion grew, the presbyters (i.e., the leaders of the various groups of Christians), encountering disagreement about fundamentals of the Christian message, felt the need to settle on a uniform doctrine they would all agree to teach, which they would expect their flocks to obey, on pain of excommunication. This, Hobbes says, was 'the first knot upon their liberty'. Then as the number of presbyters grew, the presbyters in the chief cities persuaded their provincial colleagues to accept their authority, and took for themselves the title of bishop. 'This was the second knot on Christian liberty'. The final step was for the bishop of Rome, the imperial city, with the assistance of the emperor, to acquire authority over all the bishops of the empire. This 'was the third and last knot, and the whole synthesis and construction of the pontifical power'.

Hobbes claims that the early history of the church has been replayed in reverse in the history of England since the Reformation:

First the power of the Popes was dissolved totally by Queen Elizabeth, and the bishops, who before exercised their functions in the right of the Pope, did afterwards exercise the same in right of the Queen and her successors.... And so was untied the first knot. After this the Presbyterians lately in England obtained the putting down of the episcopacy. And so was the second knot dissolved. And almost at the same time the power was taken also from the Presbyterians. ${ }^{47}$ And so we are reduced to the independency of the primitive Christians, to follow Paul, or Cephas, or Apollos, every man as he liketh best. Which, if it be without contention, and without measuring the doctrine of Christ by our affection to the person of his minister, ... is perhaps the best..$^{48}$

Tuck describes this passage as 'the most passionate defense of toleration to be found in the book'. I think it constitutes his best evidence for regarding the English Leviathan as a defence of toleration. But when we take it together with the many other passages in which Hobbes emphasizes the need for the sovereign to have the authority to control people's utterances and actions, and to try to control their opinions, the overall evidence suggests a more nuanced verdict: that the English Leviathan is more favorable to toleration than it might appear, though not, on the whole, so favorable as the Latin Leviathan.

The passage under consideration (Lev., xlvii, 20, 385/48I-2), which Hobbes omitted from the Latin Leviathan, probably because 
it looked, after the Restoration, uncomfortably like support for Cromwell, continues by explaining that the independency of the primitive Christians is 'perhaps the best' because

there ought to be no power over the consciences of men but of the Word itself, working faith in every one, not always according to the purpose of them that plant and water, but of God himself, that giveth increase. And ... because it is unreasonable (in them who teach there is such danger in every little error) to require of a man endued with reason of his own, to follow the reason of any other man, or of the most voices of many other men (which is little better than to venture his salvation at cross and pile).

Locke could hardly have said it better. At moments like this Hobbes does indeed sound like a saint of liberalism.

Hobbes does not want to pull down all the churches, just the ones that seek to dictate to their members what they should believe and how they should act. Part of his way of doing that is to challenge the standard interpretations of the scriptural texts on which they base their claims to authority. Part of his way is to sow doubt about the authority of Scripture itself. But the part of his procedure I have concentrated on here is his debunking analysis of the psychology that leads some men to seek authority over others, and others to be foolish enough to give it to them. When he is in that mode, Hobbes acts like a card-carrying member of the radical Enlightenment, bent on destroying the influence of a clergy whose access to wealth, honor and power depends on their being widely perceived as godly men, who have a special insight into saving truths and only the good of their flocks at heart. With Voltaire, he says: 'Ecrasez l'infâme'.

To the extent that Hobbes had that project, and succeeded in it, he served the cause of religious toleration. Wherever there is a clergy, in the sense relevant here - a politically powerful group of men, whose power depends on their ability to persuade their fellow men that they have a privileged access to religious truth, which they can use to help their fellow men attain the greatest possible good, and avoid the worst possible evil - wherever there is a clergy in that sense, there is a force that has a strong incentive to work against religious liberty and is thus very apt to pose an obstacle to liberty. Diminishing the power of such a clergy removes that obstacle.

Those who have a more benign view of the clergy than Hobbes did, and are less willing than he for secular rulers to have unchecked 
power, may object that it is often useful for there to be a force in society which can oppose them. When I presented this paper in Washington, Mary Keys observed that the Catholic Church had played a valuable role in ending the communist domination of Poland. I am sure there are many other cases where organized religion has been a force for good in politics. Whether there are many cases where the power of organized religion has advanced the cause of religious liberty is another matter, about which I am not so sanguine.

\section{NOTES}

I. The phrase is Alan Ryan's. See his 'A more tolerant Hobbes', in Justifying Toleration, ed. by Susan Mendus (Cambridge: Cambridge University Press, 1988). Ryan had previously explored issues relating to Hobbes and toleration in 'Hobbes, toleration and the inner life', in The Nature of Political Theory, ed. by David Miller and Larry Seidentop (Oxford: Clarendon Press, I983).

2. But not as thoroughgoing a separation as some Americans might think their constitutional tradition requires. As Maurice Cranston has pointed out ('John Locke and the Case for Toleration', in On Toleration. ed. by Susan Mendus and David Edwards [Oxford: Clarendon Press, 1987]), although Locke says that 'the church is absolutely separate and distinct from the commonwealth and civil affairs', he has no objection to indeed, assumes that there will be - a state church, and that the state will use persuasion to 'draw the heterodox to truth'. He objects only to the state's use of commands backed by the threat of force. See John Locke, Epistola de Tolerantia, A Letter on Toleration, ed. by Raymond Klibansky, trans. by J. W. Gough (Oxford: Clarendon Press, I968), 69, 85 .

3. Lev., xviii, 9 (9I/II3-I4); xxix, 6-8 (I68-9/2I2-I3); Xxx, 2-I4 (I75$80 / 2$ I9-26).

4. In each case Hobbes seems to reject the teaching of St. Paul: 'By grace you have been saved through faith, and this is not your own doing; it is the gift of God, not the result of works, so that no one may boast' (Ephesians 2:8). 'When the Gentiles, who do not possess the law, do instinctively what the law requires, these, though not having the law, are a law unto themselves. They show that what the law requires is written on their hearts, to which their own conscience bears witness; and their conflicting thoughts will accuse or perhaps excuse them on the day when, according to my gospel, God, through Jesus Christ, will judge the secret thoughts of all' (Romans 2:14-16).

5. In the articles cited in n. 2 . 
6. See Hobbes's explanation of why Constantine and the other Roman emperors found it necessary to establish many penalties against heretics, in the Latin Leviathan, Appendix ii, 44 (Curley edn, 53 I).

7. See Lev., xl, 2 (249-50/3 I7-I8); xlii, 43 (285/354); xlvi, 37 (378/466); Latin Leviathan, Appendix ii, 64 (Curley edn, 536).

8. The Elements of Law, Natural and Politic, ed. by Ferdinand Tönnies (2nd ed., London: Frank Cass, I969), II, ix, 4.

9. Behemoth, ed. by Stephen Holmes /Chicago: University of Chicago Press, I990), 62.

Io. See Behemoth, Holmes ed., 6I-2, 73.

I I. See his 'Hobbes and Locke on Toleration', in Thomas Hobbes and Political Theory, ed. by Mary G. Dietz (Lawrence: University Press of Kansas, I990), I 53-7I. Tuck, however, draws a sharp distinction between the Hobbes of Leviathan and the Hobbes of De Cive, which he claims is 'a defense of religious repression' (p. I65).

I2. For example, Latin Leviathan, Appendix ii, 57-64 (Curley edn, 535-6).

I3. Latin Leviathan, Appendix i, Io4 (Curley edn, 520-I).

I4. Hobbes discusses the parable of the weeds in the wheat in the Latin Appendix ii, 66 (Curley edn, 536-7). This parable was a staple of the argument for toleration in the early modern period. See my 'Sebastian Castellio's Erasmian Liberalism', Philosophical Topics, 3 I (2004): 47-73.

I 5. In his 'Essay on Toleration', written in I667, but not published until the nineteenth century. Locke's earlier Two Tracts on Government (I660, I662), written before his association with Shaftesbury, had defended the right of rulers to impose the use of indifferent things (i.e., things neither commanded nor forbidden by God) in religious worship. For these texts see David Wootton's edition of Locke's Political Writings (New York: Mentor, I993). In his introduction Wootton suggests that by I667 Locke may have been persuaded by the failure of the Clarendon Code, which attached severe civil disabilities to nonconformity, that it was impossible to enforce religious uniformity. The 'Essay on Toleration' anticipates the doctrine of separation Locke was to defend in his better known Epistola de tolerantia of $\mathrm{I} 685$.

I6. John Aubrey, Brief Lives, Chiefly of Contemporaries, ed. by Andrew Clark (Oxford: Clarendon Press, I898), I, 339.

I7. Leviathan itself, however, was burned at Oxford in I683. See Patricia Springborg, 'Hobbes, Heresy and the Historia Ecclesiastica', Journal of the History of Ideas, 55 (I994): 556.

I8. Hobbes had argued for this distinction between the imperatives of the Old Testament (genuine commands and therefore, since they came from one having the appropriate authority, laws) and those of the New (merely counsel and hence not laws) in Lev., xxv, I-I I (I3 I-4/I65-9). 
I9. In my 'Sebastian Castellio's Erasmian Liberalism'.

20. For Aquinas see Summa theologiae II-II, qu. I I, art. 3. For Calvin see his The Defense of the Orthodox Faith (I 554). So both Aquinas and Calvin would have had a ready reply to the Lockean objection that because a saving faith must be voluntary, it is not possible to coerce someone into being saved. I discuss both these passages in 'Sebastian Castellio's Erasmian Liberalism'.

2I. Radical Enlightenment, Philosophy and the Making of Modernity, I650-I750 (Oxford: Oxford University Press, 200I).

22. In this, I agree with Noel Malcolm's criticism of Israel in his Aspects of Hobbes, (Oxford: Oxford University Press, 2002), 535-7, and with at least part of the more wide-ranging criticism which Patricia Springborg has made of Israel's work in her review of Malcolm in the British Journal for the History of Philosophy, I 2 (2004): 5 I3-34.

23. That Hobbes was covertly either an atheist or a deist was the thesis of my "'I Durst Not Write So Boldly," or How to Read Hobbes's TheologicalPolitical Treatise', in Hobbes e Spinoza, ed. by Daniela Bostrenghi (Naples: Bibliopolis, I992). (By 'deist' I understand a monotheist who believes that God has not revealed himself to man either directly or through any set of scriptures.) I take Hobbes's professions of orthodoxy to be a nonculpable deception which the religious intolerance of his day required him to adopt, if he was to sow doubt about the dominant religious beliefs, as I think he meant to do. The quotation in the title of this article is taken from Aubrey's report of Hobbes's reaction to reading Spinoza's Tractatus Theologico-Philosophicus. For the context of the quote, see the excerpt from Aubrey's life of Hobbes in the Curley edition of Leviathan, p. lxviii, which I believe gives a more accurate version of Aubrey's report than the one printed in Clark's edition of Brief Lives. In personal communication Israel tells me that he has subsequently modified his reading of Hobbes's religious views, in response both to my work and to criticisms from Noel Malcolm and Kinch Hoekstra. He now thinks he was inclined to take Hobbes's statements about religion too literally when he dismissed him as a radical Enlightenment figure.

24. In the seventeenth century Henry Oldenburg seems not to have realized, from a reading of the Theological-Political Treatise, just how radical Spinoza's thought was. See my 'Homo Audax: Leibniz, Oldenburg and the Theological-Political Treatise', in Studia Leibnitiana, supp. I99I. For a more recent example, see Graeme Hunter's Radical Protestantism in Spinoza's Thought (Aldershot: Ashgate, 2005).

25. De corpore xxvi, I, in Hobbes, Opera Latina, ed. by William Molesworth, I, 337 (orig. published in London in I839, reprinted in I966 by 
Scientia Verlag, Aalen, Germany). My translation. Hobbes criticizes arguments against the eternity of the world on similar grounds in his Thomas White's DE MUNDo Examined, trans. by Harold Whitmore Jones (Bradford: Bradford University Press, I976), ch. 28. The topic recurs in the Appendix to the Latin Leviathan, ch. i. On this see Patricia Springborg's analysis in her 'Hobbes and Epicurean Religion', in Der Garten und die Moderne: Epikureische Moral und Politik vom Humanismus bis zur Aufklarung, ed. by Gianni Paganini and Edoardo Tortarolo (Stuttgart-Bad Cannstatt: Rommann-holzboog Verlag, 2004), I6I-2I4. Gianni Paganini has also explored Hobbes's relationship to Epicureanism in his 'Hobbes, Gassendi, and the Tradition of Political Epicureanism', in Hobbes Studies, I4 (200I): 3-24.

26. The passage from De corpore is complex. For further discussion see 'I Durst Not Write So Boldly', 572-82.

27. For further discussion of these issues see my 'The Covenant with God in Hobbes's Leviathan', in Leviathan after 350 Years, ed. by Tom Sorell and Luc Foisneau (Oxford: Clarendon Press, 2004).

28. Lev., xxxi, I3, I90/239. In the Latin Leviathan Hobbes softens the English Leviathan's blunt statement that God has no ends: 'But I see no end on account of which God omnipotent might wish himself to be worshipped, except that it might benefit us'. Hobbes, Opera Latina, ed. by W. Molesworth (London: J. Bohn, I84I), 259.

29. Briefly, the argument is that on Hobbes's definition of a command (Lev., XXV, 2, I 3 I-2/I 65-6), someone who commands something does so for his own benefit. And on Hobbes's definition of law (Lev., xxvi, 2, I37/I73), law is a command addressed to someone previously obliged to obey the commander. But if God has no ends, he cannot act for his own benefit, and so cannot issue commands, and so cannot be a lawgiver. For further discussion see my 'Religion and Morality in Hobbes', in Rational Commitment and Social Justice, Essays for Gregory Kavka, ed. by Jules Coleman and Christopher Morris (Cambridge: Cambridge University Press, I998), IO2-5.

30. In the Theological-Political Treatise, ch. 6. Part of Spinoza's argument is that, since God is normally thought to have been the author of the laws of nature, he would be acting contrary to his own will if he interfered with the operation of those laws.

3I. Lev., xxxvii, I2, 236-7/298-9. The Latin reads 'two wicked men conspiring'.

32. So far as I know, the only passage in which Spinoza discusses hell occurs in the Short Treatise on God, Man and his Well-Being, II, xviii, 6 (Spinoza, Collected Works, Princeton: Princeton University Press, I 985 ), I, I 28 . 
33. Lev., xxxviii, 6-I 4, 242-5/305-9; xliv, I4-I6, 339-40/4I 8-20; xliv, 27-9, 345-46/426-9. Hobbes also deals with the doctrine of eternal torment in the Appendix to the Latin Leviathan (i, 43-6, Curley edn, 506-7), where to his usual scriptural arguments he adds the claim that God's infinite mercy would enable him, without injustice, to remit the eternal punishment the wicked might deserve.

34. I have discussed the roles Hobbes and Spinoza played in this discipline in 'Notes on a Neglected Masterpiece (I): Spinoza and the Science of Hermeneutics', in Spinoza, the Enduring Questions, ed. by Graeme Hunter (Toronto: University of Toronto Press, I994). See also Noel Malcolm's 'Hobbes, Ezra and the Bible', in his Aspects of Hobbes.

35. Theological-Political Treatise, xii, I (Gebhardt edition, III, I58, my translation).

36. Malcolm, Aspects of Hobbes, 428.

37. For details, see Bruce Metzger and Bart Ehrman, The Text of the New Testament, Its Transmission, Corruption and Restoration, $4^{\text {th }}$ edition (Oxford: Oxford University Press, 2005), ch. iii, or Bart Ehrman, Misquoting Jesus, The Story Behind Who Changed the Bible and Why (San Francisco: Harper, 2005), 78-83.

38. See Lev., xlii, 3, 267-9/334-6. Hobbes deleted this passage from the Latin edition of Leviathan, but returned to the topic in his Appendix, i, 87, Curley edn, 5 I7. I pass over another notorious example of pious fraud, the so-called Donation of Constantine, unmasked by Lorenzo Valla in the fifteenth century. On Hobbes' relation to Valla, see Gianni Paganini's 'Thomas Hobbes e Lorenzo Valla,' Rinascimento 39 (I999): 5 I 5-68.

39. See Bart Ehrman, The Orthodox Corruption of Scripture, The Effects of Early Christological Controversies on the Text of the New Testament (Oxford: Oxford University Press, I993), or chapter 6 of his Misquoting Jesus.

40. See the Latin Leviathan, Appendix, ii, I-26, Curley edn, 52 I-6.

4I. Hobbes's treatment of the doctrine of the Trinity in the English Leviathan (e.g., in xvi, I2, 82/I03; xxxiii, 20, 204-5/258-9; and xlii, $3,267-8 / 334-6)$ would be an example of what I take to be a clear embrace of heresy, which required considerable backtracking in the Latin Leviathan. See the annotation in the Curley edition of the passages cited earlier and Hobbes's retraction in the Appendix, iii, I I-I4, Curley edn, 543.

42. Brief Lives, I, 358. For Spinoza's similar view of the clergy, see the Preface to his Theological-Political Treatise.

43. See the Appendix to the Latin Leviathan, iii, 27-8, Curley edn, 545. 
44. See Robert S. Paul, The Assembly of the Lord, Politics and Religion in the Westminster Assembly and the 'Grand Debate' (Edinburgh: T. \& T. Clark, I985), 5 I 8.

45. John Moorman writes, of the period immediately following the execution of Charles, that 'the religious life of the country was in a state of great confusion. Since the abolition of episcopacy there had been no proper organization or control. Most of the incumbents were Presbyterians, but a number were Anglicans at heart, who conformed under protest, and a few were Independents. All that the government could do was to issue an order in I650 to say that everyone must attend some place of worship or a place where religious exercises were held; but that meant very little'. A History of the Church in England (London: Adam and Charles Black, I954), 243-4.

46. The Latin Leviathan here reads: 'the way to eternal salvation'. Curley edn, 290.

47. A reference, I take it, to the expulsion of the Presbyterian members from the House of Commons in Pride's Purge, December I648.

48. Lev., xlvii, 20 (385/48I-2). For the sake of readability, I omit, in the first ellipsis, a significant parenthetical remark: 'though by retaining the phrase of jure divino, they were thought to demand it by immediate right from God'. Hobbes is understating matters here. Not only were the bishops thought to demand their authority 'by immediate right from God', they did so demand it. And Hobbes knew this at least by the time he wrote Behemoth. See pp. 56-7 in the Holmes edition.

\section{REFERENCES}

Aubrey, John, Brief Lives, Chiefly of Contemporaries, ed. by Andrew Clark, Oxford, Clarendon Press, I 898, 2 vols.

Cranston, Maurice, 'John Locke and the Case for Toleration', in On Toleration, ed. by Susan Mendus and David Edwards, Oxford, Clarendon Press, I987.

Curley, Edwin, 'Homo Audax: Leibniz, Oldenburg and the TheologicalPolitical Treatise', Studia Leibnitiana, supp. I99I.

Curley, Edwin, "'I Durst Not Write So Boldly," or How to Read Hobbes's Theological-Political Treatise', in Hobbes e Spinoza, ed. by Daniela Bostrenghi, Naples, Bibliopolis, I992, pp. 497-593.

Curley, Edwin, 'Notes on a Neglected Masterpiece (I): Spinoza and the Science of Hermeneutics', in Spinoza, the Enduring Questions, ed. by Graeme Hunter, Toronto, University of Toronto Press, I 994.

Curley, Edwin, 'Religion and Morality in Hobbes', in Rational Commitment and Social Justice, Essays for Gregory Kavka, ed. by Jules Coleman and Christopher Morris, Cambridge, Cambridge University Press, I998. 
Curley, Edwin, 'The Covenant with God in Hobbes's Leviathan', in Leviathan after 350 Years, ed. by Tom Sorell and Luc Foisneau, Oxford, Clarendon Press, 2004.

Curley, Edwin, 'Sebastian Castellio's Erasmian Liberalism', Philosophical Topics, 3 I (2004): 47-73.

Ehrman, Bart, The Orthodox Corruption of Scripture, The Effects of Early Christological Controversies on the Text of the New Testament, Oxford, Oxford University Press, I 993.

Ehrman, Bart, Misquoting Jesus, The Story Behind Who Changed the Bible and Why, San Francisco, Harper, 2005.

Hobbes, Thomas, Behemoth, ed. by Stephen Holmes, Chicago, University of Chicago Press, I990.

Hobbes, Thomas, The Elements of Law, ed. by F. Tönnies, 2nd ed., London, Franks Cass \& Co., Ltd., I969.

Hobbes, Thomas, Leviathan, with selected variants from the Latin edition of I 668, ed. by Edwin Curley, Indianapolis, Hackett Publishing Company, I994.

Hobbes, Thomas, Opera Latina, ed. by W. Molesworth, London, J. Bohn, I84I.

Hobbes, Thomas, Thomas White's De Mundo Examined, trans. by Harold Whitmore Jones, Bradford, Bradford University Press, I976.

Hunter, Graeme, Radical Protestantism in Spinoza's Thought, Aldershot, Ashgate, 2005.

Israel, Jonathan, Radical Enlightenment, Philosophy and the Making of Modernity, I650-I750, Oxford, Oxford University Press, $200 \mathrm{I}$.

Jordan, W. K., The Development of Religious Toleration in England, From the convention of the Long Parliament to the Restoration, I640-I660, Cambridge, Mass., Harvard University Press, 1938.

Locke, John, Epistola de Tolerantia, A Letter on Toleration, ed. by Raymond Klibansky, trans. by J. W. Gough, Oxford, Clarendon Press, I968.

Locke, John, Political Writings, ed. by David Wootton, New York, Mentor, I993.

Malcolm, Noel, Aspects of Hobbes, Oxford: Oxford University Press, 2002.

Metzger, Bruce, and Ehrman, Bart, The Text of the New Testament, Its Transmission, Corruption and Restoration, 4th edn, Oxford, Oxford University Press, 2005.

Moorman, John, A History of the Church in England, London, Adam and Charles Black, I954.

Paganini, Gianni, 'Thomas Hobbes e Lorenzo Valla', in Rinascimento, 39 (I999): 5 I 5-68.

Paganini, Gianni, 'Hobbes, Gassendi, and the Tradition of Political Epicureanism', in Hobbes Studies, I4 (200I): 3-24. 
Paul, Robert S., The Assembly of the Lord, Politics and Religion in the Westminster Assembly and the 'Grand Debate,' Edinburgh, T. \& T. Clark, I985.

Ryan, Alan, 'Hobbes, toleration and the inner life', in The Nature of Political Theory, ed. by David Miller and Larry Seidentop, Oxford, Clarendon Press, I983.

Ryan, Alan, 'A more tolerant Hobbes', in Justifying Toleration, ed. by Susan Mendus, Cambridge, Cambridge University Press, I988.

Spinoza, Benedict de, Opera, ed. by Carl Gebhardt, Heidelberg, Carl Winters, 4 vols., I 925 .

Spinoza, Benedict de, The Collected Works of Spinoza, ed. by Edwin Curley, vol. I, Princeton, Princeton University Press, I985.

Springborg, Patricia, 'Hobbes, Heresy and the Historia Ecclesiastica', in Journal of the History of Ideas, 55 (I994): 553-7 I.

Springborg, Patricia, 'Hobbes and Epicurean Religion', in Der Garten und die Moderne: Epikureische Moral und Politik vom Humanismus bis zur Aufklarung, ed. by Gianni Paganini and Edoardo Tortarolo, Stuttgart-Bad Cannstatt, Rommann-holzboog Verlag, 2004.

Springborg, Patricia, review of Malcolm's Aspects of Hobbes, British Journal for the History of Philosophy, I2 (2004): 5 I 3-34.

Tuck, Richard, 'Hobbes and Locke on Toleration', in Thomas Hobbes and Political Theory, ed. by Mary G. Dietz, Lawrence, University Press of Kansas, I990. 